\title{
$\mathrm{J}$ $\mathrm{NAH}$
}

ISSN 2333-0694

\section{EFFECTS OF SEX, ENVIRONMENT, AND CONDITION ON THE MUSKING BEHAVIOR OF SYMPATRIC GARTERSNAKES (THAMNOPHIS SPP.)}

\author{
ERIC J. GANGLOFF ${ }^{1,3}$, DAVID BERTOLATUS², CHRISTOPHER REIGEL ${ }^{2}$, \\ AND JENNIFER L. GAGLIARDI-SEELEY² \\ ${ }^{1}$ Department of Ecology, Evolution, and Organismal Biology, Iowa State University, Ames, IA 50011, \\ USA \\ ${ }^{2}$ Department of Biology, Metropolitan State University of Denver, CO 80217, USA \\ ${ }^{3}$ CORRESPONDENCE: e-mail, gangloff@iastate.edu
}

\begin{abstract}
Despite an abundance of studies documenting antipredator and defensive behaviors of gartersnakes (genus Thamnophis), few have quantitatively examined musking, a widely utilized antipredator tactic. In this study we quantify musking behaviors in the Terrestrial Gartersnake (Thamnophis elegans) and the Plains Gartersnake ( $T$. radix) when hand-captured at four sites in and near Denver, Colorado, USA. Overall, Plains Gartersnakes musked significantly more often than Terrestrial Gartersnakes. Female Terrestrial Gartersnakes musked more frequently than males, a pattern not evident in the Plains Gartersnake. Additionally, we observed a positive correlation in body condition and musking propensity in Terrestrial Gartersnakes, suggesting resource-dependent behavior in this species. Musking behavior was consistent across variations in predation pressure, environmental conditions, and snake body size, all factors shown to influence other gartersnake defensive behaviors. These results corroborate other research which demonstrates that snake antipredator behaviors are determined by complex interactions of abiotic and biotic factors.
\end{abstract}

Key words: antipredator behavior, body condition, gartersnake, musking, predation, Thamnophis elegans, Thamnophis radix, urbanization

\section{INTRODUCTION}

Avoiding predators generally increases individual fitness; however, antipredator strategies vary in their energetic demands and are constrained by the morphology and/or physiology of both predator and prey species (Greene, 1994). It has been suggested that optimization of antipredator strategies is necessary because such behaviors are costly when employed unnecessarily (Ives and Dobson, 1987; Lima and Dill, 1990). Because of their high degree of behavioral variability, snakes have long been utilized as model organisms for understanding the underlying mechanisms of variation in predator response (Greene, 1979; Mori and Burghardt, 2004). Previous work has demonstrated that antipredator behaviors in snakes are determined by a complex interaction of genetic (Scudder and Burghardt, 1983; Arnold and Bennett, 1984; Herzog and Burghardt, 1986; Brodie, 1989; Herzog and Schwartz, 1990; Placyk and Burghardt, 2011) and environmental influences, includ- ing temperature (Mori and Burghardt, 2004), individual state (Shine et al., 2000; Roth and Johnson, 2004; Aubret et al., 2007), and predation pressure (Aubret et al., 2011; Placyk, 2012). Comparative studies of these variations can shed light on the evolution of behavioral phenotypes and population differentiation (Burghardt and Schwartz, 1999; Llewelyn et al., 2010).

Musking, or cloacal discharge, is a common defensive behavior across many snake taxa that involves the release of a foul-smelling secretion from the cloacal glands, often accompanied by feces and urates (Mori and Burghardt, 2008; Placyk, 2012), to render the snake unappetizing to potential predators (Blum et al., 1971; Mason, 1992). Musk gland secretions are primarily composed of lipids and vary in composition across taxa (OIdak, 1976). Oleic and linoleic acids create the repellent smell (Blum et al., 1971), distinct from odors of feces or urates (Watkins et al., 1969; Chiszar et al., 1980). The muscles surrounding the musk gland ducts in the later- 
al margins of the cloaca are favorable for quick release such as is necessary in defensive encounters (Price and Lapointe, 1981). Potential predators including housecats (Wright and Weldon, 1990), ants (Gehlbach et al., 1968), and ophiophagus snakes (Watkins et al., 1969) were deterred by musking secretions in laboratory observations, though canids were not (Weldon and Fagre, 1989). Musking has been observed without being quantified in numerous snake antipredator behavior studies (Fitch, 1965; Scudder and Burghardt, 1983; Arnold and Bennett, 1984; Graves and Duvall, 1988; Ford and Burghardt, 1993; Keogh and DeSerto, 1994; Glaudas, 2004). Studies that have quantified musking behavior demonstrate that it is a last-line defense, not occurring until the snake is physically handled (Gibbons and Dorcas, 2002; Mori and Burghardt, 2008).

This study quantified musking behavior in two snake species: the Terrestrial Gartersnake (Thamnophis elegans Baird and Girard, 1853) and the Plains Gartersnake ( $T$. radix Baird and Girard, 1853), in response to human predators at four sites in and near Denver, Colorado, USA. Here the geographic distributions of these two closely-related species (Pyron et al., 2011) intersect in the vicinity of a growing urban center, the Front Range of Colorado (Rossman et al., 1986; Hammerson, 1999). Humans and their companion animals are important predators of snakes in urban environments because of intentional harassment, collection, poaching, and disturbance due to proximity (Burger, 2001). Gartersnakes are sometimes common in these environments and are apparently able, at least in the short-term, to survive in such impacted and patchy habitats (Rossman et al., 1986; Kjoss and Litvaitis, 2001; Mifsund and Mifsund,
2008; Patrick and Gibbs, 2009). It is unknown if their behavior and/or natural history traits differ in these areas as has been found in a wide range of vertebrate taxa (Ditchkoff et al., 2006).

We tested four hypotheses of the plasticity of gartersnake musking behavior in response to humans, which snakes perceive as potential predators (Herzog et al., 1989; Prior and Weatherhead, 1994; Gregory and Gregory, 2006): (i) given that musk gland morphology (Young et al., 1999) and antipredator displays (Greene, 1979) are closely associated with ecological demands and habitat type, these species will exhibit an equal propensity to musk when living side-by-side under identical ecological pressures; (ii) both species will increase musking frequency in habitats of greater predation pressure from humans (approximated by habitat size and distance from the city center) and other animals (as approximated by incidence of scarring and tail loss (e.g., Placyk and Burghardt, 2005)); (iii) snakes in better body condition will be more likely to exhibit musking behavior because of the energetic costs of lipid production (Derickson, 1976); and (iv) given intersexual differences in musk lipid composition (Oldak, 1976), musk gland morphology (Kissner et al., 1998; Young et al., 1999), and musk odor (Kissner et al., 2000), females will musk more frequently than males.

\section{METHODS}

Field methods - Observations were made at four sites in and near Denver, Colorado, USA, varying in size and level of human impact: Commons Park, a downtown city park; Lowry Wetlands, an unimproved watershed on a former Air Force base; Bluff Lake Nature Center, an ur-

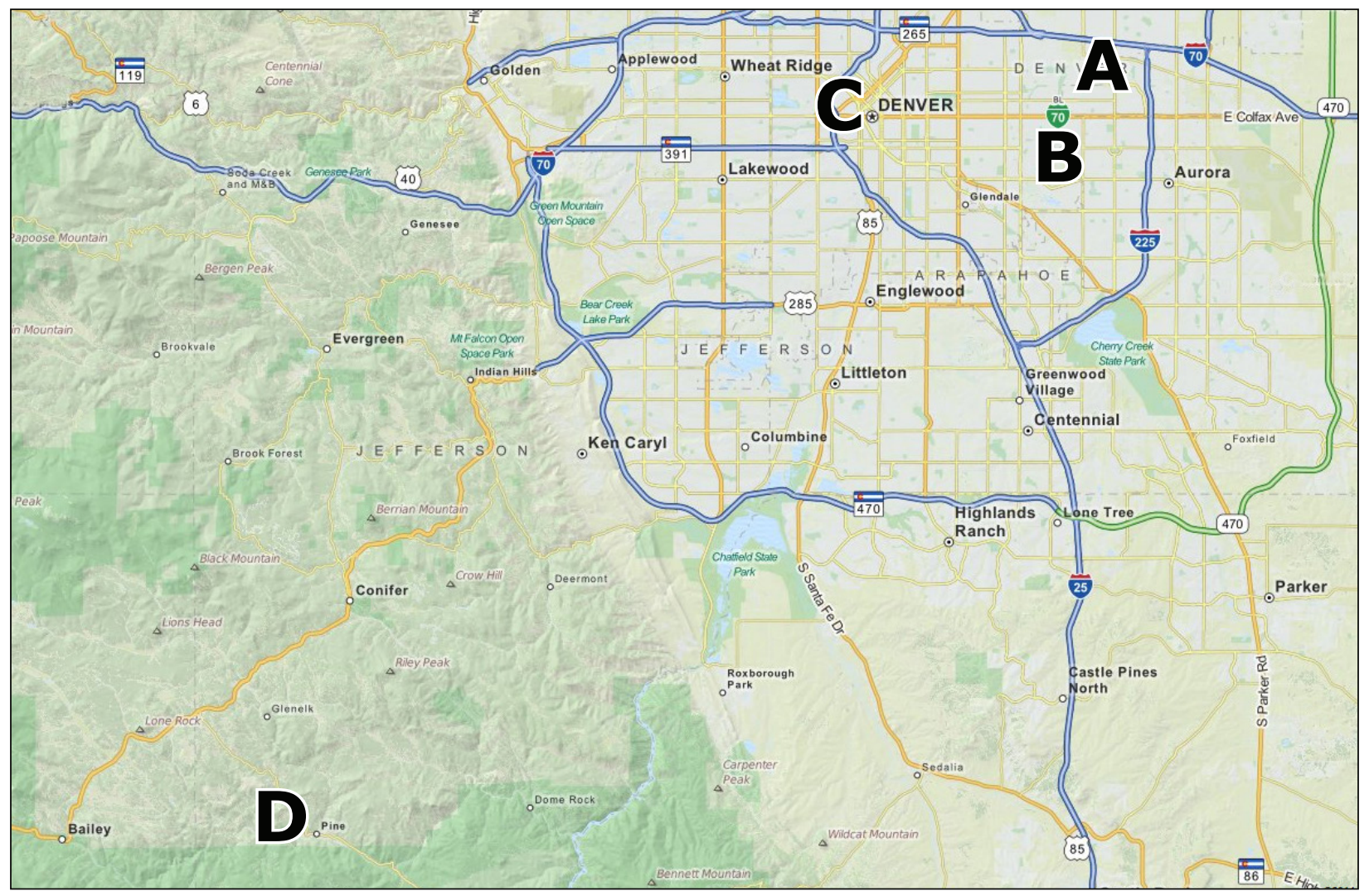

Figure 1. Map of the greater metro area of Denver, Colorado, USA, showing location of study sites. A) Bluff Lake Nature Cener, B) Lowry Wetlands, C) Commons Park, and D) Pine Valley Ranch Park. Source MapQuest.com. 
ban nature preserve formerly part of Stapleton International Airport; and Pine Valley Ranch Park, a county park in a large swath of contiguous habitat ( $>5,000 \mathrm{~km}^{2}$ ) (see Figure 1, Table 1). Only Terrestrial Gartersnakes were found at the Pine Valley Ranch Park site, while both species were found at the remaining three sites. We hand-captured snakes on open ground and under cover objects from March-November 2009, March-November 2010, March-September 2011, and April-October 2012. Musking was defined as the release of cloacal secretions and a foul smell and was recorded as a binary (yes/no) response if it occurred at any time during processing. Air temperature was measured immediately after capture 2 $\mathrm{cm}$ above ground level (PTH8708 Digital Temperature \& Humidity Pen, General Tools, New York). We measured snake mass with spring scales (Pesola AG, Baar, Switzerland) and snout-vent length with a standard tape measure. We recorded any indications of previous injury, including body scars and missing tail tips, and individually marked snakes by ventral scale clipping (Brown and Parker, 1976). After processing, all snakes were released at point of capture. Identical protocols were followed for each snake and processing time varied only nominally. Because habituation can occur among gartersnakes in behavior studies (e.g., Andry and Luttges, 1972; Chiszar et al., 1976; Herzog et al., 1989; Herzog, 1990; Placyk and Burghardt, 2011), only data from first captures were utilized in analysis. Simultaneous captures were also excluded from analysis due to the uncertainty of positively identifying the musking snake. We cleaned our hands with moist towelettes and hand sanitizer (containing minimum $62 \%$ isopropyl alcohol) after each encounter. Field protocols during the 2012 season were modified slightly from previous years and included a measure of body temperature via cloacal probe and sexing; because of this difference in procedure we analyzed these data separately.

Statistical methods - We conducted a Fisher's Exact Test to test for differences in musking behavior between species from the three sympatric sites and from all four sites in observations during 2009-2011. To test for the effects of predation pressure and body condition on musking behavior we created logistic regression models for each species independently, using habitat size, distance from downtown Denver, incidence of scarring, and body condition as predictor variables and snake size (snout-vent length, SVL) and air temperature as covariates. Because mass and snout-vent length were highly correlated $\left(R^{2}=0.761\right)$, only snout-vent length was included in models as a metric of snake size. Snake body condition was calculated as the residuals of the regression of the log of body weight on the log of SVL (Weatherhead and Brown, 1996) using separate regression lines for each species. To test for sex differences, we conducted a Fisher's Exact Test for each species using data from the 2012 observations. All analyses were conducted in SAS 9.2 (SAS Institute, Cary, NC) with $a=0.05$.

\section{RESULTS}

In observations during 2009-2011 at the three sympatric sites, the Plains Gartersnake $(n=37)$ musked significantly more frequently than the Terrestrial Gartersnake $(n=75)(91.9 \%$ of encounters vs. $57.3 \%$; Fisher's Exact Test $P<0.001$ ). The inclusion of data from a fourth site, where Plains Gartersnakes are not found, did not alter the results, with $60.2 \%$ of Terrestrial Gartersnakes $(\mathrm{n}=98)$ musking (Fisher's Exact Test $\mathrm{P}<0.001$; See Figure 2). As such, data from all four sites were used in subsequent analyses. For the Terrestrial Gartersnake, individuals in better body condition were significantly more likely to musk (Type III test of fixed effects, $F_{1,91}$ $=6.75, P=0.01)$. No other factors in the models for either species were significant (all $P \geq 0.13$; see Table 2). In 2012, under slightly different field protocols, the Plains Gartersnake ( $n=20)$ again musked significantly more frequently than the Terrestrial Gartersnake ( $\mathrm{n}$ $=37)(80.0 \%$ of encounters vs. $51.3 \%$; Fisher's Exact Test $P=0.047$ ). Additionally, there was a significant sex difference within Terrestrial Gartersnakes, with females musking more often than males $(82.3 \%$ of encounters vs. $25.0 \%$; Fisher's Exact Test $P<0.001)$, but no sex difference within Plains Gartersnakes $(66.7 \%$ of encounters vs. $91.0 \%$; Fisher's Exact Test $P=0.28$; See Figure 3). A post-hoc logistic regression showed significant interaction between species and body condition (Wald $\mathrm{X}_{1}^{2}=$ 6.667, P < 0.001), with Terrestrial Gartersnakes musking with greater frequency as body condition increased. An opposite, though not statistically significant, trend was evident in Plains Gartersnakes (See Figure 4).

\section{DISCUSSION}

These observations do not support our hypothesis of convergent musking behaviors of snakes living sympatrically or the hypothesis of variation across a gradient of habitat size and anthropogenic impact. The Plains Gartersnake musked significantly more often than the Terrestrial Gartersnake at the three sympatric sites. Furthermore, musking did not correlate with differences in environmental variables, habitat differences, or metrics of predation pressure in either species. As

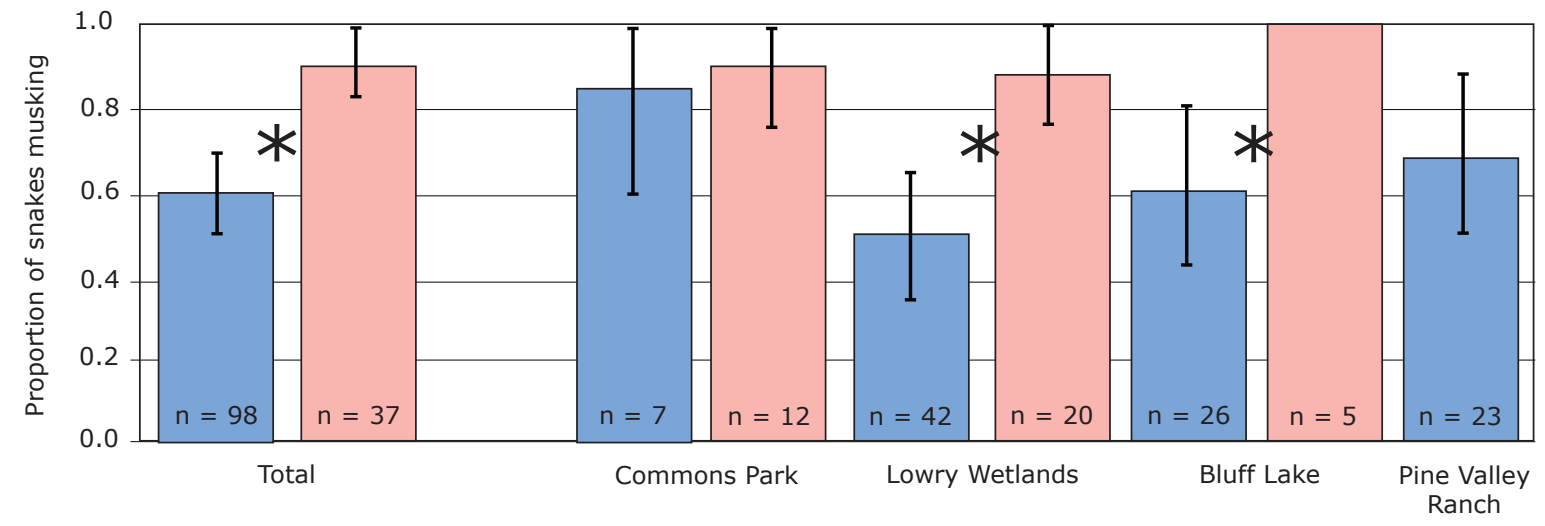

Figure 2. Proportion musking by the Terrestrial Gartersnake (Thamnophis elegans, blue) and the Plains Gartersnake ( $T$. radix, red) at each location during 2009-2011. Asterisks indicate significant $(P<0.05)$ differences; error bars show $95 \%$ confidence limits. 
Table 1. Description of study sites near Denver, CO.

\begin{tabular}{|c|c|c|c|c|c|}
\hline Site name & $\begin{array}{c}\text { Approximate } \\
\text { area }\end{array}$ & $\begin{array}{l}\text { Distance } \\
\text { from } \\
\text { downtown } \\
\text { Denver }\end{array}$ & $\begin{array}{l}\text { Surrounding } \\
\text { area }\end{array}$ & $\begin{array}{l}\text { Latitude/ } \\
\text { Longitude } \\
\text { (datum = } \\
\text { WGS84) }\end{array}$ & $\begin{array}{l}\text { Species } \\
\text { present and } \\
\text { sample size } \\
(2009-2011)\end{array}$ \\
\hline Commons Park & 10 ha & $0 \mathrm{~km}$ & $\begin{array}{l}\text { dense urban } \\
\text { development; high- } \\
\text { rise buildings, retail } \\
\text { business, } \\
\text { residential buildings }\end{array}$ & $\begin{array}{c}39.758089^{\circ} \\
-105.004844^{\circ}\end{array}$ & $\begin{array}{c}\text { Plains Gartersnake } \\
(n=12) \\
\text { Terrestrial Gartersnake } \\
(n=7)\end{array}$ \\
\hline Lowry Wetlands & 20 ha & $12 \mathrm{~km}$ & $\begin{array}{l}\text { urban development; } \\
\text { primarily single- } \\
\text { family residential }\end{array}$ & $\begin{array}{c}39.727361^{\circ} \\
-104.889742^{\circ}\end{array}$ & $\begin{array}{c}\text { Plains Gartersnake } \\
(n=20) \\
\text { Terrestrial Gartersnake } \\
(n=42)\end{array}$ \\
\hline $\begin{array}{l}\text { Bluff Lake } \\
\text { Nature Center }\end{array}$ & 50 ha & $14 \mathrm{~km}$ & $\begin{array}{l}\text { urban development; } \\
\text { single-family } \\
\text { residential and } \\
\text { industrial; open } \\
\text { space; county jail }\end{array}$ & $\begin{array}{c}39.758875^{\circ} \\
-104.857611^{\circ}\end{array}$ & $\begin{array}{c}\text { Plains Gartersnake } \\
(n=5) \\
\text { Terrestrial Gartersnake } \\
(n=26)\end{array}$ \\
\hline $\begin{array}{l}\text { Pine Valley } \\
\text { Ranch Park }\end{array}$ & 332 ha & $70 \mathrm{~km}$ & $\begin{array}{l}\text { sparse residential } \\
\text { development; } \\
\text { continuous with } \\
\text { national forest }\end{array}$ & $\begin{array}{c}39.408975^{\circ} \\
-105.349792^{\circ}\end{array}$ & $\begin{array}{l}\text { Terrestrial Gartersnake } \\
\qquad(n=23)\end{array}$ \\
\hline
\end{tabular}

observations from 2012 indicate no sex bias in observations $\left(X_{1}^{2}=0.439, P=0.57\right)$, we have no reason to believe that the observations from previous years are biased because of differences in the number of each sex included.

Consistency of musking antipredator behavior was also found by Placyk (2012), who quantified behaviors in snakes from populations of differing predation threat and found that population of origin had a significant effect on musking behavior, but handling by humans did not. Taken together with our findings, this implies that antipredator decisions in gartersnakes may be determined genetically or canalized early in development, with neither immediate conditions nor recent experience influencing antipredator decisions. Our observations were made within the narrow geographic band, along the high plains east of the Rocky Mountains, in which the Terrestrial Gartersnake and the Plains Gartersnake are sympatric (Hammerson, 1999). Further observations across the distribution of these species, as well as quantification of predation pressures, could illuminate the evolutionary trajectories that have shaped this behavioral divergence. Interestingly, our hypothesis for higher propensity to musk with increasing body condition was supported for

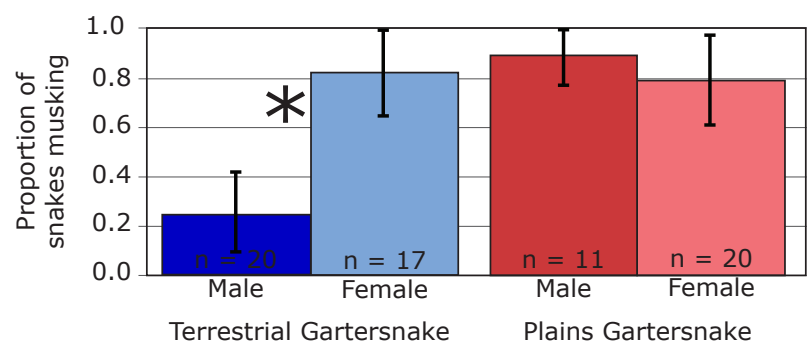

Figure 3. Proportion musking by sex and species during 2012. Asterisk indicates significant $(P<0.05)$ difference; error bars show $95 \%$ confidence limits. the Terrestrial Gartersnake, but not in the Plains Gartersnake. Musking in Terrestrial Gartersnakes may be subject to condition-dependent physiological limitations. On the other hand, musking defense was used consistently by Plains Gartersnakes in the vast majority of encounters, possibly indicative of a species-level canalization of this behavior. The opposing trend in musking propensity with increasing body condition in the Plains Gartersnake, though not significant, could perhaps be due to the implementation of alternative defensive tactics such as writhing or biting in robust individuals.

Our hypothesis of sex-biased musking was observed in the Terrestrial Gartersnake, contrary to our observations of Plains Gartersnakes and a study of Common Gartersnake (Thamnophis sirtalis Linnaeus, 1758) populations

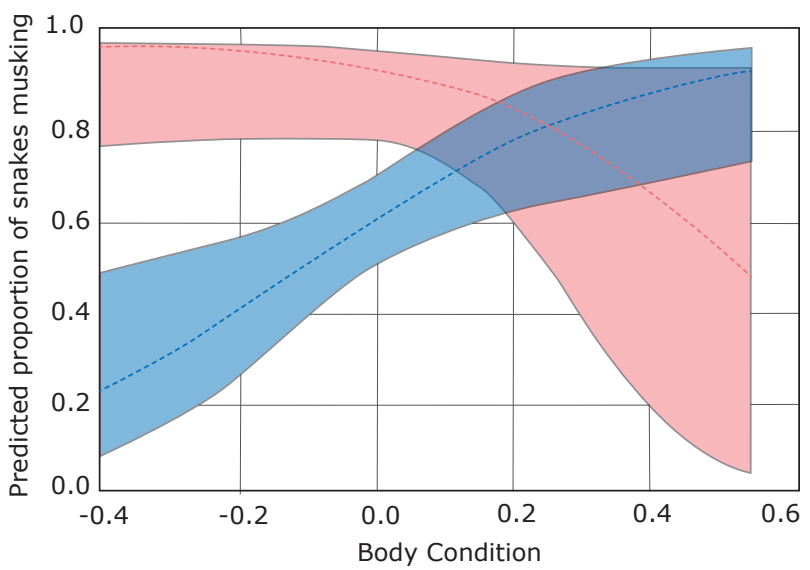

Figure 4. Predicted probabilities of musking by body condition, with $95 \%$ confidence envelope, for the Terrestrial Gartersnake (Thamnophis elegans, blue) and the Plains Gartersnake ( $T$. radix, red). The trend in Terrestrial Gartersnakes is statistically significant $(P=0.001)$. 
Table 2. Type III parameter estimates, t-statistics, and P-values of factors associated with musking behavior in the Terrestrial Gartersnake (Thamnophis elegans) and the Plains Gartersnake (T. radix) from logistic regression models. Significant results in bold typeface and underlined.

\begin{tabular}{|c|c|c|c|c|c|c|}
\hline \multirow[b]{2}{*}{ Predictor Variable } & \multicolumn{3}{|c|}{$\begin{array}{l}\text { Plains Gartersnake ( } T \text {. radix) } \\
\text { at } 3 \text { sites }(n=37)\end{array}$} & \multicolumn{3}{|c|}{$\begin{array}{c}\text { Terrestrial Gartersnake }(T \text {. elegans }) \\
\text { at } 4 \text { sites }(n=98)\end{array}$} \\
\hline & $\begin{array}{c}\text { Parameter } \\
\text { estimate }( \pm \mathrm{SE})\end{array}$ & $\begin{array}{l}\text { t-statistic } \\
\quad(\text { d.f. })\end{array}$ & P-value & $\begin{array}{c}\text { Parameter } \\
\text { estimate }( \pm \mathrm{SE})\end{array}$ & $\begin{array}{l}\text { t-statistic } \\
\quad(\text { d.f. })\end{array}$ & P-value \\
\hline $\begin{array}{l}\text { Air temperature } \\
\text { (range: } 15.4-45.2^{\circ} \mathrm{C} \text { ) }\end{array}$ & $\begin{array}{c}0.408 \\
( \pm 0.293)\end{array}$ & $\begin{array}{l}1.39 \\
(30)\end{array}$ & 0.174 & $\begin{array}{c}0.00541 \\
( \pm 0.0530)\end{array}$ & $\begin{array}{l}0.10 \\
(91)\end{array}$ & 0.919 \\
\hline $\begin{array}{l}\text { Snout-vent length } \\
\text { (range: } 140-680 \mathrm{~mm} \text { ) }\end{array}$ & $\begin{array}{c}-0.00066 \\
( \pm 0.00791)\end{array}$ & $\begin{array}{c}-0.08 \\
(30)\end{array}$ & 0.934 & $\begin{array}{c}0.000424 \\
( \pm 0.00210)\end{array}$ & $\begin{array}{l}0.20 \\
(91)\end{array}$ & 0.841 \\
\hline Body condition & $\begin{array}{c}-6.881 \\
( \pm 5.914)\end{array}$ & $\begin{array}{r}-1.16 \\
(30)\end{array}$ & 0.254 & $\begin{array}{c}4.061 \\
( \pm 1.563)\end{array}$ & $\begin{array}{l}2.60 \\
(91)\end{array}$ & $\underline{0.011}$ \\
\hline $\begin{array}{l}\text { Habitat size } \\
\text { (range: } 10-332 \text { ha) }\end{array}$ & $\begin{array}{c}0.333 \\
( \pm 19.201)\end{array}$ & $\begin{array}{l}0.02 \\
(30)\end{array}$ & 0.218 & $\begin{array}{c}0.0313 \\
( \pm 0.0206)\end{array}$ & $\begin{array}{l}1.52 \\
(91)\end{array}$ & 0.132 \\
\hline $\begin{array}{l}\text { Distance from } \\
\text { downtown Denver } \\
\text { (range: } 0-70 \mathrm{~km} \text { ) }\end{array}$ & $\begin{array}{c}-0.0794 \\
( \pm 16.003)\end{array}$ & $\begin{array}{l}0.00 \\
(30)\end{array}$ & 0.996 & $\begin{array}{c}-0.160 \\
( \pm 0.107)\end{array}$ & $\begin{array}{c}-1.49 \\
(91)\end{array}$ & 0.139 \\
\hline Scarring & $\begin{array}{c}-15.283 \\
( \pm 495.97)\end{array}$ & $\begin{array}{l}-0.03 \\
(30)\end{array}$ & 0.976 & $\begin{array}{c}0.216 \\
( \pm 0.519)\end{array}$ & $\begin{array}{l}0.42 \\
(91)\end{array}$ & 0.679 \\
\hline
\end{tabular}

in Michigan (Placyk, 2006). The impacts of body condition and sex observed in the Terrestrial Gartersnake may be related. For example, if females musk more often and are in better body condition, perhaps as the result of stores for reproduction, we would expect such a positive relationship between condition and musking in this species. This difference in strategy may be due to sex-biased predation pressure leading to differing tactics between males and females, sex differences in the energy budgets and resource allocation in this species, or perhaps as a corollary to other functions of the musk glands. Males and females react differently to the odors of the opposite sex, thereby raising the possibility that musking could serve in complex chemosensory social interactions (Roth and Lutterschmidt, 2011). Additionally, musking may serve as a cue alerting conspecifics to potential predators, but evidence of this is limited to anecdotal observations and one laboratory experiment (Brisbin, 1968; Duvall et al., 1985; Graves and Duvall, 1988). Our understanding of the implications of musking in snake social behavior would benefit greatly from further tests of the influence of sex and condition as well responses to conspecific musking.

As with other studies of antipredator behaviors, a lack of observations of natural predator-prey interactions challenges our complete understanding (Gregory and Gregory, 2006). A variety of variables found to influence snake behavior, including stress, feeding condition, shedding cycle, and hydration (Ford, 1995) are not accounted for in the present study and may confound any observations of snake behavior in the field. However as variation in laboratory and field behaviors has been shown in gartersnakes (Brodie, 1993), an examination of animal behaviors in natural contexts can provide critical insights unavailable from laboratory experiments alone (Altmann, 1974). Given the ease with which musking can be observed and recorded concomitant with a variety of snake field studies, it would be most useful for research- ers to record such data across a wide range of geography and taxonomy.

\section{ACKNOWLEDGMENTS}

Fieldwork was greatly assisted by J. Derosby, J. Gangloff, L. Roth, R. Slater, C. Tomlin, T. Tran, J. Zion, and P.S. 1 Charter School students. K. Pazdernik of the ISU Statistic Consulting Group provided guidance in data analysis. Bluff Lake Nature Center, Denver Parks \& Recreation, Lowry Redevelopment Authority, and Jefferson County Open Space (especially M. Morin) generously allowed access to their land and snakes. Members of the Bronikowski Lab at ISU provided helpful suggestions on the manuscript. Financial support was provided by Iowa State University Ecology \& Evolutionary Biology and Biotechnology Fellowships, the Lois Webster Fund of the Audubon Society of Greater Denver, Prairie Biotic Research, the Marv Aures/Bob Krantz Grant Fund of the Western New York Herpetological Society, and Metropolitan State University of Denver. All research conducted under license from the Colorado Division of Wildlife.

\section{LITERATURE CITED}

Altmann, J. 1974. Observational study of behavior: Sampling methods. Behaviour 49:227-267.

Andry, M.L., and M.W. Luttges. 1972. Neural habituation in garter snakes. Physiology \& Behavior 9:107-111.

Arnold, S.J., and A.F. Bennett. 1984. Behavioral variation in natural populations. III: Antipredator displays in the garter snake Thamnophis radix. Animal Behaviour 32:1108-1118.

Aubret, F., X. Bonnet, and D. Bradshaw. 2007. Food versus risk: Foraging decision in young Tiger snakes, Notechis scutatus. Amphibia-Reptilia 28:304-308.

Aubret, F., R.J. Michniewicz, and R. Shine. 2011. Correlated geographic variation in predation risk and antipredator behaviour within a wide-ranging snake species (Notechis scutatus, Elapidae). Austral Ecol- 
ogy $36: 446-452$

Blum, M.S., J.B. Byrd, J.R. Travis, J.F. Watkins, and F.R. Gehlbach. 1971. Chemistry of cloacal sac secretion of the blind snake Leptotyphlops dulcis. Comparative Biochemistry and Physiology 38:103-107.

Brisbin, I.L., Jr. 1968. Evidence for the use of postanal musk as an alarm device in the king snake, Lampropeltis getulus. Herpetologica 24:169-170.

Brodie, E.D. 1989. Genetic correlations between morphology and antipredator behavior in natural populations of the garter snake Thamnophis ordinoides. Nature 342:542-543.

Brodie, E.D. 1993. Homogeneity of the genetic variance-covariance matrix for antipredator traits in two natural populations of the garter snake Thamnophis ordinoides. Evolution 47:844-854.

Brown, W.S., and W.S. Parker. 1976. A ventral scale clipping system for permanently marking snakes (Reptilia, Serpentes). Journal of Herpetology 10:247249.

Burger, J. 2001. The behavioral reponse of basking Northern Water (Nerodia sipedon) and Eastern Garter (Thamnophis sirtalis) Snakes to pedestrians in a New Jersey park. Urban Ecosystems 5:119-129.

Burghardt, G.M., and J.M. Schwartz. 1999. Geographic variations on methodological themes in comparative ethology: A natricine snake perspective, pp. 69-94 in S. A. Foster and J. A. Endler (eds.), Geographic Variation in Behavior: Perspectives on Evolutionary Mechanisms. Oxford University Press, New York.

Chiszar, D., T. Carter, L. Knight, L. Simonsen, and S. Taylor. 1976. Investigatory behavior in plains garter snake (Thamnophis radix) and several additional species. Animal Learning and Behavior 4:273-278.

Chiszar, D., S. Wellborn, M.A. Wand, K.M. Scudder, and H.M. Smith. 1980. Investigatory behavior in snakes, II: Cage cleaning and the induction of defecation in snakes. Animal Learning and Behavior 8:505-510.

Derickson, W.K. 1976. Lipid storage and utilization in reptiles. American Zoologist 16:711-723.

Ditchkoff, S.S., S.T. Saalfeld, and C.J. Gibson. 2006. Animal behavior in urban ecosystems: Modifications due to human-induced stress. Urban Ecosystems 2006:5-12.

Duvall, D., M.B. King, and K.J. Gutzwiller. 1985. Behavioral ecology and ethology of the prairie rattlesnake. National Geographic Research 1:80-111.

Fitch, H.S. 1965. An ecological study of the garter snake, Thamnophis sirtalis. University of Kansas, Lawrence, Kansas.

Ford, N.B. 1995. Experimental design in studies of snake behavior. Herpetological Monographs 9:130-139.

Ford, N.B., and G.M. Burghardt. 1993. Perceptual mechanisms and the behavioral ecology of snakes, pp. 117-154 in R. A. Siegel and J. T. Collins (eds.), Snakes: Ecology and Behavior. McGraw-Hill, Inc., New York.

Gehlbach, F.R., J.F. Watkins, and H.W. Reno. 1968. Blind snake defensive behavior elicited by ant attacks. Bioscience 18:784-785.

Gibbons, J.W., and M.E. Dorcas. 2002. Defensive behavior of Cottonmouths (Agkistrodon piscivorus) toward humans. Copeia 2002:195-198.

Glaudas, X. 2004. Do Cottonmouths (Agkistrodon piscivorus) habituate to human confrontations? Southeastern Naturalist 3:129-138.

Graves, B.M., and D. Duvall. 1988. Evidence of an alarm pheromone from the cloacal sacs of prairie rattlesnakes. Southwestern Naturalist 33:339-345.

Greene, H.W. 1979. Behavioral convergence in the defensive displays of snakes. Experientia 35:747-748.

Greene, H.W. 1994. Antipredator mechanisms in reptiles, pp. 1-329 in C. Gans and B. H. Raymond (eds.), Biology of the Reptilia: Volume 16, Ecology B, Defense and Life History. Branta Books, Ann Arbor, MI.

Gregory, P.T., and L.A. Gregory. 2006. Immobility and supination in garter snakes (Thamnophis elegans) following handling by human predators. Journal of Comparative Psychology 120:262-268.

Hammerson, G.A. 1999. Amphibians and Reptiles in Colorado. University Press of Colorado, Niwot, CO.

Herzog, H.A. 1990. Experiential modification of defensive behaviors in garter snakes (Thamnophis sirtalis). Journal of Comparative Psychology 104:334-339.

Herzog, H.A., B.B. Bowers, and G.M. Burghardt. 1989. Stimulus control of antipredator behavior in newborn and juvenile garter snakes (Thamnophis). Journal of Comparative Psychology 103:233-242.

Herzog, H.A., and G.M. Burghardt. 1986. Development of antipredator responses in snakes: I. Defensive and open-field behaviors in newborns and adults of three species of garter snakes (Thamnophis melanogaster, $T$. sirtalis, $T$. butleri). Journal of Comparative Psychology 100:372-379.

Herzog, H.A., and J.M. Schwartz. 1990. Geographical variation in the antipredator behavior of neonate garter snakes, Thamnophis sirtalis. Animal Behaviour 40:597-598.

Ives, A.R., and A.P. Dobson. 1987. Antipredator behavior and the population dynamics of simple predator-prey systems. American Naturalist 130:431-447.

Keogh, J.S., and F.P. Deserto. 1994. Temperature dependent defensive behavior in 3 species of North American colubrid snakes. Journal of Herpetology 28:258-261.

Kissner, K.J., G. Blouin-Demers, and P.J. Weatherhead. 2000. Sexual dimorphism in malodorousness of musk secretions of snakes. Journal of Herpetology 34:491-493.

Kissner, K.J., D.M. Secoy, and M.R. Forbes. 1998. Sexual dimorphism in size of cloacal glands of the garter snake, Thamnophis radix haydeni. Journal of Herpetology 32:268-270.

Kjoss, V.A., and J.A. Litvaitis. 2001. Community structure of snakes in a human-dominated landscape. Biological Conservation 98:285-292.

Lima, S.L., and L.M. Dill. 1990. Behavioral decisions made under the risk of predation: a review and prospectus. Canadian Journal of Zoology 68:619-640.

Llewelyn, J., J.K. Webb, and R. Shine. 2010. Flexible defense: Context-depended antipredator responses of two species of Australian elapid snakes. Herpetologica 66:1-11.

Mason, R.T. 1992. Reptilian pheromones, pp. 114-228 in C. Gans and D. Crews (eds.), Biology of the Reptilia: Volume 18, Physiology E, Hormones, Brain, and Behavior. University of Chicago Press, Chicago.

Mifsund, D.A., and R. Mifsund. 2008. Golf courses as refugia for herpetofauna in an urban river floodplain, pp. 303-310 in J. C. Mitchell, R. E. Jung Brown, and B. Bartholomew (eds.), Urban Herpetology. Society for the Study of Reptiles and Amphibians, Salt Lake City.

Mori, A., and G.M. Burghardt. 2004. Thermal effects 
on the antipredator behaviour of snakes: A review and proposed terminology. Herpetological Journal 14:79-87.

Mori, A., and G.M. Burghardt. 2008. Comparative experimental tests of natricine antipredator displays, with special reference to the apparently unique displays in the Asian genus, Rhabdophis. Journal of Ethology 26:61-68.

Oldak, P.D. 1976. Comparison of scent gland secretion lipids of twenty-five snakes: Implications for biochemical systematics. Copeia 1976:320-326.

Patrick, D.A., and J.P. Gibbs. 2009. Snake occurrences in grassland associated with road versus forest edges. Journal of Herpetology 43:716-720.

Placyk, J.S. 2006. Historical processes, evolutionary change, and phenotypic plasticity: Geographic variation in behavior, morphology, and life-history traits of common gartersnake, Thamnophis sirtalis, populations. PhD dissertation, University of Tennessee, Knoxville.

Placyk, J.S. 2012. The role of innate and environmental influences in shaping antipredator behavior of mainland and insular gartersnakes (Thamnophis sirtalis). Journal of Ethology 30:101-108.

Placyk, J.S., and G.M. Burghardt. 2005. Geographic variation in the frequency of scarring and tail stubs in eastern gartersnakes (Thamnophis s. sirtalis) from Michigan, USA. Amphibia-Reptilia 26:353-358.

Placyk, J.S., and G.M. Burghardt. 2011. Evolutionary persistence of chemically elicited ophiophagous antipredator responses in gartersnakes (Thamnophis sirtalis). Journal of Comparative Psychology 125:134-142.

Price, A.H., and J.L. Lapointe. 1981. Structure-functional aspects of the scent gland in Lampropeltis getulus splendida. Copeia 1981:138-146.

Prior, K.A., and P.J. Weatherhead. 1994. Response of free-ranging eastern massasauga rattlesnakes to human disturbance. Journal of Herpetology 28:255257.

Pyron, R.A., F.T. Burbrink, G.R. Colli, A.N.M. De Oca, L.J. Vitt, C.A. Kuczynski, and J.J. Wiens. 2011. The phylogeny of advanced snakes (Colubroidea), with discovery of a new subfamily and comparison of support methods for likelihood trees. Molecular Phylogenetics and Evolution 58:329-342.

Rossman, D.A., N.B. Ford, and R.A. Siegel. 1986. The Garter Snakes: Evolution and Ecology. University of Oklahoma Press, Norman, OK.

Roth, E.D., and J.A. Johnson. 2004. Size-based variation in antipredator behavior within a snake (Agkistrodon piscivorus) population. Behavioral Ecology 15:365370.

Roth, E.D., and W.I. Lutterschmidt. 2011. Experimental validation of sex differences in spatial behavior patterns of free-ranging snakes: Implications for social interactions. Ethology 117:852-858.

Scudder, R.M., and G.M. Burghardt. 1983. A comparative study of defensive behavior in thee sympatric species of water snakes (Nerodia). Zeitschrift für Tierpsychologie 63:17-26.

Shine, R., M.M. Olsson, M.P. Lemaster, I.T. Moore, and R.T. Mason. 2000. Effects of sex, body size, temperature, and location on the antipredator tactics of free-ranging gartersnakes (Thamnophis sirtalis, Colubridae). Behavioral Ecology 11:239-245.

Watkins, J.F., F.R. Gehlbach, and J.C. Kroll. 1969. Attractant-repellent secretions of blind snakes (Leptotyphlops dulcis) and their army ant prey (Neivamyrmex nigrescens). Ecology 50:1098-1102.

Weatherhead, P.J., and P.J. Brown. 1996. Measurement versus estimation of condition in snakes. Canadian Journal of Zoology 74:1617-1621.

Weldon, P.J., and D.B. Fagre. 1989. Responses by canids to scent gland secretions of the western diamondback rattlesnake (Crotalus atrox). Journal of Chemical Ecology 15:1589-1604.

Wright, J., and P.J. Weldon. 1990. Responses by domestic cats (Felis catus) to snake scent gland secretions. Journal of Chemical Ecology 16:2947-2953.

Young, B.A., C. Marsit, and K. Meltzer. 1999. Comparative morphology of the cloacal scent gland in snakes (Serpentes : Reptilia). Anatomical Record 256:127138. 